\section{Analysis of Employment in the Illinois Nursery Industry}

\author{
T.M. Waliczek, ${ }^{1}$ P.D. O’Rourke, ${ }^{2}$ and J.C. Bradley ${ }^{3}$
}

Additional INDEX wORDs. education, training, recruitment, employees, retention, salary, benefits, hire

Summary. Horticulture crops are a multimillion dollar industry in Illinois, providing employment opportunities as well as strengthening many local economies. In February 1998, about 300 surveys were mailed to members of the Illinois Nurserymen's Association, including owners and operation managers of retail and wholesale nurseries, greenhouses and garden centers. Questions included the pool of available labor, the total number of persons employed, including full and part-time workers, starting and average salaries for employees, retention rates and training procedures. Questions were also asked regarding employees' education and experience level, average compensation for various levels of employment and demographics of the employee pool. A $48 \%$ response rate was achieved with 147 surveys returned and analyzed. Respondents reported an average of 70 employees including sales staff, office staff and seasonal employees. Those businesses responding employed an average of 2.5 managers with an approximate annual salary of $\$ 48,000$, and an average of 15 laborers with an approximate annual salary of $\$ 21,000$. Correlations provided insight into which areas of the industry hired persons with horticulture degrees and the types of experience most valued by the respondents.

$\mathrm{T}$ he horticultural industry throughout the United States is comprised of many units including those that produce, sell, distribute and provide service to clients. Illinois is part of a subgroup of states, the eastern north-central region, that has historically been a significant contributor to the production and consumption of horticultural crops (Bordelon et al., 1997). Illinois is an important producer of fruit, berries, and landscape and ornamental horticultural products including apples (Malus $\times$ domestica), peaches (Prunus persica), cut flowers, potted flowering plants, foliage, and bedding plants (Illinois Agricultural Statistics Service, 1997).

The value of U.S. horticultural products was $\$ 36$ billion in 1995 and is expected to continue growing until the year 2005 for both edible and ornamental products (USDA, 1997). Consumption of fruit and vegetables in the United States has increased over the past 2 decades. Per capita produce consumption is expected to continue rising as a result of dietary concerns and the aging population (Bordelon et al., 1997; Putnam and Allshouse, 1996). Similarly, consumers have invested more dollars toward aesthetic horticulture products over the past 10 years than they have ever before. Americans spend an average of $\$ 350$

\footnotetext{
Department of Agriculture, Illinois State University, Normal, IL 61790-5020.

${ }^{1}$ Assistant professor; corresponding author (tcl0@swt.edu).

${ }^{2}$ Professor

${ }^{3}$ Assistant professor, Department of Environmental Horticulture, University of
} Florida, Gainesville, FL 32611-0670. per person annually on ornamental horticulture products such as cut flowers, foliage, and potted flowering plants (Bordelon et al., 1997).

Because of this growth in the industry, there has been concern about the increasing problem of recruiting and retaining qualified employees to meet the horticulture industry's current and future needs [Human Resources Development Canada (HRDC), 1992]. However, little information is available on the horticulture labor force (Smith et al., 1990). To gain better insight into the industry, it is essential to examine its status. The objectives of this study were to ascertain business ownership, recruiting and training techniques, type of positions, length of service, salary and payroll figures, as well as overall employee demographics. Examining this information will provide valuable insight for businesses seeking successful transitions and increased growth in the future.

\section{Materials and methods}

In February 1998, 304 surveys were mailed to owners and operation managers of retail and wholesale nurseries, greenhouses and garden centers registered as active members of the Illinois Nurserymen's Association (Springfield, Ill.). The survey was modeled after similar instruments used by other universities (Lard et al., 1996; Rhodus and Hoskins, 1996). The survey consisted of questions concerning the types of positions employed within the company, average salaries and benefits provided to employees, types of training provided, recruiting tools used and the years of service employees gave to companies. Questions were also included to collect employee demographic information such as gender, ethnicity and age. Reminder postcards were sent to increase response rates. All data were analyzed using the Statistical Package for the Social Sciences for Windows release 10.0 (SPSS, Chicago). During statistical analyses, any missing responses to survey questions were coded as missing values. Descriptive statistics such as frequencies and percentages were calculated for all variables of interest. Multivariate analysis of variance (MANOVA) tests were conducted to determine the differences in business responses. MANOVA tests are commonly used when determining whether groups differ on more than one dependent variable (Borg and Gall, 1989). Additionally, posthoc analyses (LSD) were used to help identify where differences were occurring. Pearson product-moment correlations were conducted to compare variables of interest. Correlation statistics are commonly computed to help describe the strength of the relationship between two variables. A perfectly positive relationship will be indicated with a value of 1.0 , while a perfectly negative relationship would be a value of -1.0 (Borg and Gall, 1989).

\section{Results and discussion}

Of the 304 surveys sent to businesses, 147 were returned, for a return rate of $48 \%$. This level of response was adequate for supplying ideas for the given sample population, but is not necessarily intended for generalizations to other populations. In addition, findings from the analysis of this survey data reflect the situation that existed at the time the respondents returned the survey. Data results indicated the types of businesses (wholesale and retail nurseries, greenhouses and garden centers) that were included in the study group as a whole. It should also be noted that while 
Table 1. Frequencies and percentages of industry survey responses $(n=140)$ indicating business structure as sole proprietorship, corporation, partnership, or limited liability corporation.

\begin{tabular}{lcc}
\hline \multirow{2}{*}{$\begin{array}{l}\text { Typeofbusiness } \\
\text { structure }\end{array}$} & \multicolumn{2}{c}{ Industrysurveyresponses } \\
\cline { 2 - 3 } & Businesses(no.) & Businesses(\%) \\
\hline Sole proprietorship & 79 & 56.4 \\
Corporation & 48 & 34.3 \\
Partnership & 11 & 7.9 \\
Limited liability corporation & 2 & 1.4 \\
\hline
\end{tabular}

Table 3. Frequencies and percentages of industry survey responses $(n=131)$ indicating those businesses that expect a percent change in the business labor force within 5 years.

\begin{tabular}{lcc}
\hline \multirow{2}{*}{$\begin{array}{l}\text { Change } \\
\text { expected(\%) }\end{array}$} & \multicolumn{2}{c}{ Industrysurveyresponses } \\
\cline { 2 - 3 }-50 & 2 & Responses(\%) \\
-10 & 2 & 1.5 \\
$0 /$ no change & 44 & 1.5 \\
5 & 4 & 33 \\
8 & 1 & 3.1 \\
10 & 19 & 0.8 \\
15 & 14 & 14.6 \\
20 & 21 & 10.8 \\
25 & 10 & 16.2 \\
30 & 5 & 7.7 \\
50 & 5 & 3.8 \\
70 & 1 & 3.8 \\
75 & 2 & 0.8 \\
100 & 1 & 1.5 \\
\hline
\end{tabular}

some of the results of this survey support findings provided by the USDA, National Agriculture Statistics Service reports (USDA, 1998), some are conflicting due to sampling differences.

The mean for the businesses responding indicated that most businesses had one location and were either a corporation $(34 \%)$ or a sole proprietorship (56\%) (Table 1). In total, the respondents were employing about 6,343 full and part-time employees. On average, those businesses responding had 2 owners or managers, 2 superintendents, 5 foremen, 39 laborers, 3 office staff, 4 sales staff, and 15 seasonal employees (Table 2). While the value of U.S. horticultural products is expected to continue growing for the next 5 years (USDA, 1997), 33\% of respondents expected no change and 3\% expected a decrease in their own labor force within that same time frame (Table 3 ). However, about $42 \%$ of respondents expected a $10 \%$ to $20 \%$ increase in their labor force, indicating an expected growth in the company within the next 5 years.

Recruiting, hiring and retaining good employees have traditionally been a fundamental goal of businesses (Ayers and Stone, 1999), and are current con-
Table 2. Industry survey responses $(n=147)$ indicating the types of positions available within businesses, the total number of positions held within businesses and the average number of positions held by employees within companies.

\begin{tabular}{lcc}
\hline & \multicolumn{2}{c}{ Industrysurveyresponses } \\
\cline { 2 - 3 } Position & Positions(total no.) & Positions (meanno.) \\
\hline Owners/managers & 129 & 2.26 \\
Superintendents & 64 & 2.44 \\
Foremen & 97 & 4.99 \\
Laborers & 93 & 39.5 \\
Office staff & 83 & 2.89 \\
Sales staff & 50 & 4.12 \\
Seasonal employees & 87 & 14.86 \\
\hline
\end{tabular}

Table 4. Percentages of industry survey responses $(n=147)$ ranking various recruiting tools as the most valuable to their business in attracting new employees.

\begin{tabular}{lc}
$\begin{array}{l}\text { Recruiting } \\
\text { tool }\end{array}$ & $\begin{array}{c}\text { Industry survey responses } \\
\text { (\%) }\end{array}$ \\
\hline Word of mouth & 46.8 \\
Recommendation from friend/family & 43.8 \\
College/trade school & 13.7 \\
Walk-in & 8.0 \\
Newspaper advertisement & 7.4 \\
Trade magazine & 2.9 \\
Labor pool & 2.2 \\
Employment agency & 2.2 \\
Internet & 1.5
\end{tabular}

cerns in the horticulture industry with its expected growth (HRDC, 1992; USDA, 1997). Respondents ranked the value of recruiting tools from one to nine with one being the most valuable tool and nine being the least valuable tool for

Fig. 1. Industry survey responses $(n=147)$ indicating the percentage of employees trained using various methods including on-the-job, mentoring programs, orientation procedures, seasonal seminars, and videotraining. 


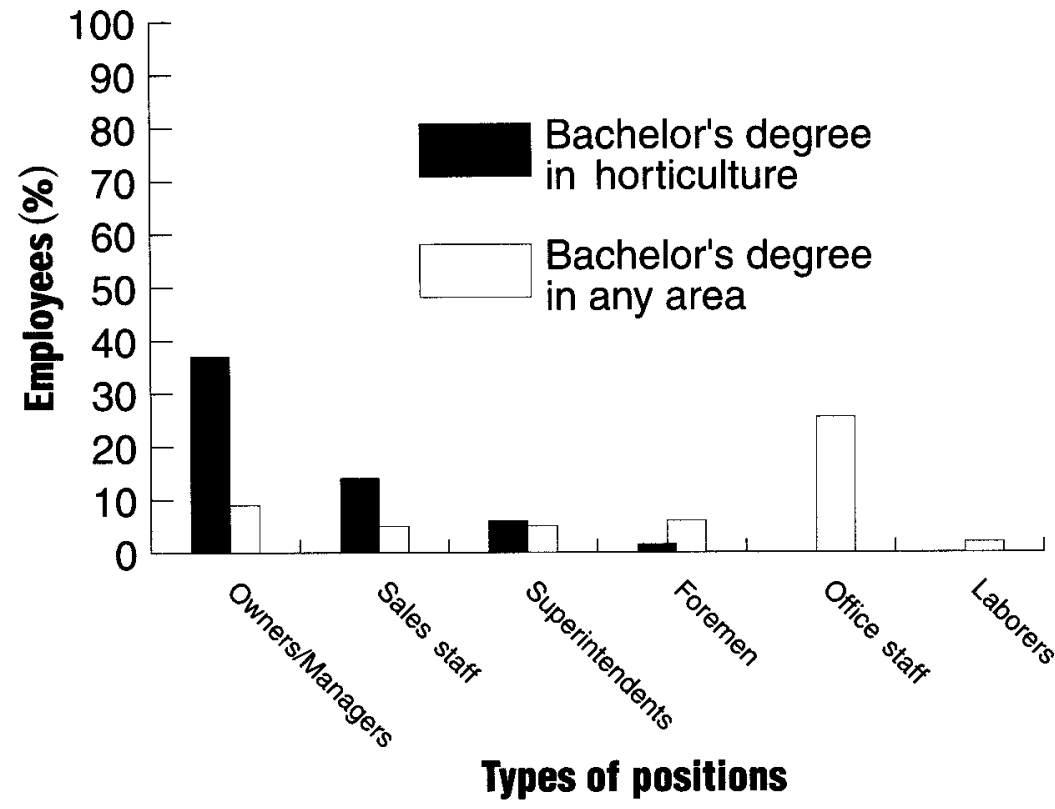

Fig. 2. Industry survey responses $(n=147)$ indicating the percentage of employees required to have a bachelor's degree in horticulture or another discipline and the types of positions employed.

recruiting employees (Table 4 ). With the availability of online resumes and advertisements in 1997 [e.g., Ferrell's Jobs in Horticulture (Tinker Graphics, 1994)], it was surprising that the Internet was ranked so low by respondents $(1.5 \%)$ as a source of connecting with potential employees. Word of mouth, referrals and family contacts were recognized as effective recruitment techniques in past studies (HRDC, 1992). Similarly, this study found word of mouth (47\%) and recommendations (44\%) were the most valuable methods for recruiting employees.

Higher levels of technology in the industry are increasing the need for more educated or trainable candidates (HRDC, 1992). Results from this study showed that employees were trained with a variety of methods, with on-the-job (98\%) and mentoring programs (45\%) (Fig. 1) ranking as those most applied. Respondents indicated that $59 \%$ of employees were required to have a bachelor's degree in horticulture (Fig. 2). About $44 \%$ of employees were hired with previous experience.

With MANOVA comparisons of business structures, it was found that corporations used training videos $(P=0.015)$ and seminars $(P=$ 0.026 ) at a statistically significantly higher rate than did sole proprietorships (Table 5). Thirty-one percent of corporations used training videos compared to $11 \%$ of sole proprietorships, and $50 \%$ of corporations incorporated seminars into training of employees compared to $26 \%$ of sole proprietorships.

Low wages are cited as a difficulty associated with recruiting and retaining a good workforce (HRDC, 1992).

Table 5. Comparisons of industry survey responses $(n=147)$ on of the types of training used by different business structures using multivariate analysis of variance.

\begin{tabular}{|c|c|c|c|c|c|c|}
\hline $\begin{array}{l}\text { Business structure } \\
\text { and type of training }\end{array}$ & 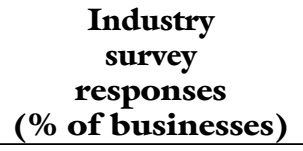 & $\begin{array}{c}\begin{array}{c}\text { Sum } \\
\text { of } \\
\text { squares }\end{array} \\
\end{array}$ & df & $\begin{array}{l}\text { Mean } \\
\text { square }\end{array}$ & $\begin{array}{c}\mathbf{F} \\
\text { value }\end{array}$ & $\boldsymbol{P}$ \\
\hline On the job & & 8.174 & 3 & 2.725 & 1.790 & 0.152 \\
\hline Corporation & 98.7 & & & & & \\
\hline Sole proprietorship & 100 & & & & & \\
\hline Partnership & 90.9 & & & & & \\
\hline Limited liability & 100 & & & & & \\
\hline Orientation & & 0.879 & 3 & 0.293 & 1.186 & 0.318 \\
\hline Corporation & 48.7 & & & & & \\
\hline Sole proprietorship & 34.8 & & & & & \\
\hline Partnership & 36.4 & & & & & \\
\hline Limited liability & 0 & & & & & \\
\hline Video & & 1.766 & 3 & 0.589 & 3.629 & 0.015 \\
\hline Corporation & 30.8 & & & & & \\
\hline Sole proprietorship & 10.9 & & & & & \\
\hline Partnership & 9.1 & & & & & \\
\hline Limited liability & 0 & & & & & \\
\hline Seminars & & 2.186 & 3 & 0.729 & 3.195 & 0.026 \\
\hline Corporation & 50.0 & & & & & \\
\hline Sole proprietorship & 26.1 & & & & & \\
\hline Partnership & 27.3 & & & & & \\
\hline Limited liability & 0 & & & & & \\
\hline Mentoring & & 1.284 & 3 & 0.428 & 1.744 & 0.161 \\
\hline Corporation & 46.2 & & & & & \\
\hline Sole proprietorship & 45.7 & & & & & \\
\hline Partnership & 27.3 & & & & & \\
\hline Limited liability & 100 & & & & & \\
\hline
\end{tabular}



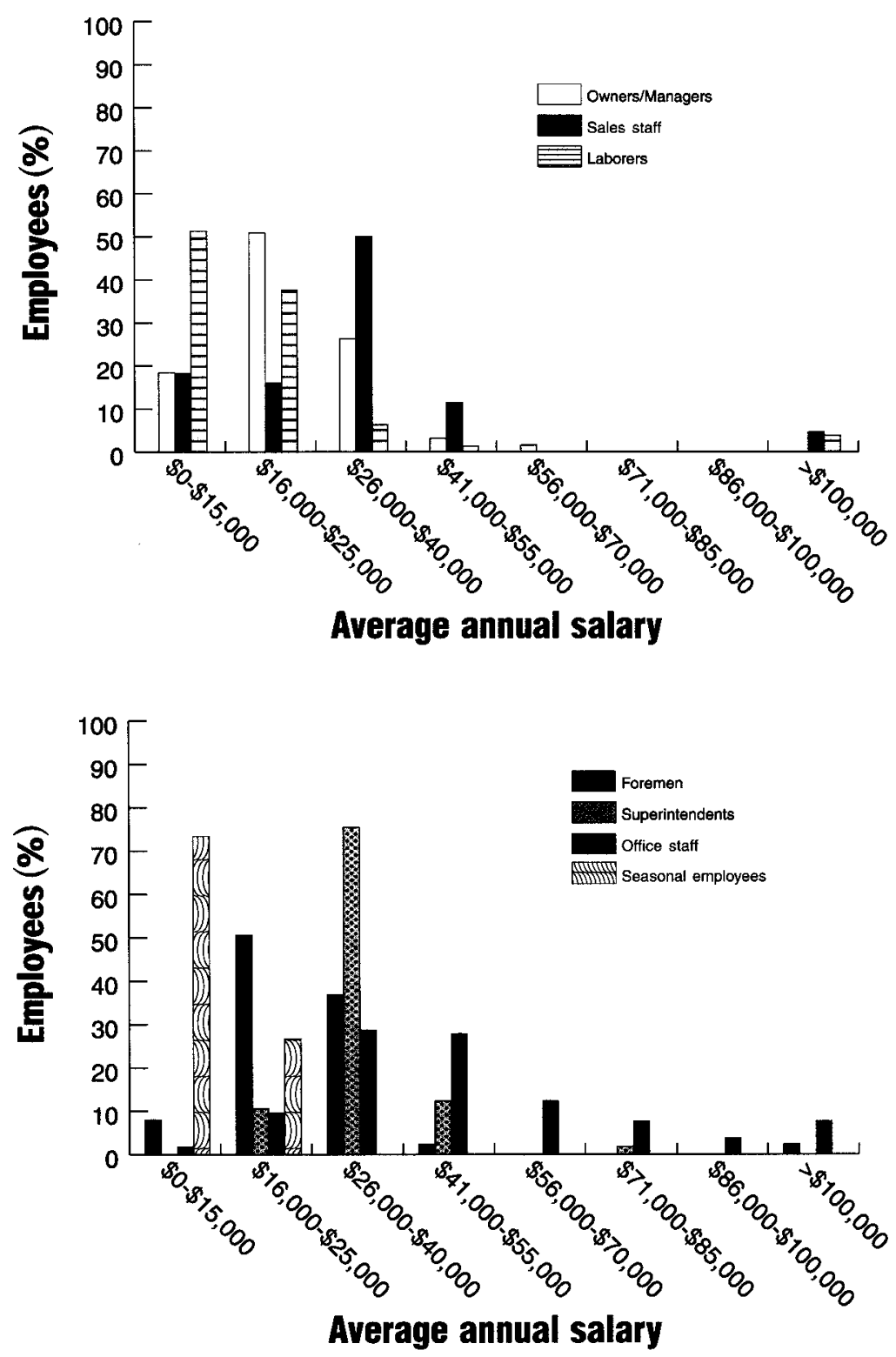

Fig. 3. (A) Industry survey responses $(n=147)$ indicating reported average annual salaries by employee classification. (B) Industry survey responses $(n=147)$ indicating reported average annual salaries by employee classification.

Table 6. Industry survey responses $(n=134)$ indicating the frequencies and percentages of nonseasonal workers employed with companies for less than 1 year to 16 or more years.

Years

Industry survey response

(no.) Nonseasonal workers (no.)Nonseasonal workers (\%)

$\begin{array}{lrr}<1 & 3 & 2.2 \\ 1-2 & 9 & 6.7 \\ 3-5 & 29 & 21.6 \\ 6-7 & 26 & 19.4 \\ 8-10 & 32 & 23.9 \\ 11-15 & 11 & 8.2 \\ \geq 16 & 24 & 17.9\end{array}$

Over $50 \%$ of laborers earned, on average for those businesses responding, between $\$ 16,000$ and $\$ 25,000$ annually, while $75 \%$ of sales staff made on average between $\$ 26,000$ and
$\$ 40,000$ each year (Fig. 3A); 50\% of superintendents also indicated salaries in that range (Fig. 3B).

Generally, nonseasonal employees were staying with companies 3 to 10 years $(65 \%)$ (Table 6$) ; 18 \%$ of employees were with companies for more than 16 years. A statistically significant difference $(P<0.01)$ was found in analysis of variance comparisons of the types of business structure and the amount of time that nonseasonal employees stayed with companies (Table 7). Post hoc analyses indicated that nonseasonal employees tended to stay with corporations longer than with sole proprietorships. Greater than $80 \%$ of the employees at corporations were reported in the 6 to 16+ years of service categories while over $50 \%$ of sole proprietorship employees were reported in the 1 to 5 year range (Table 8 ).

Since the well-known Hawthorne Studies were conducted in the 1920s to 1930s (Dickson, 1973), researchers have looked at employee motivation and found that employers' interest in supplying a safe working environment and good working conditions can be just as important as salary/pay rate (Lindner, 1998). Nearly $87 \%$ of employers carried worker's compensation, $59 \%$ of respondents provided liability insurance (Table 9), 26\% of businesses offered life insurance, and $47 \%$ offered medical insurance. Most companies also contributed other types of benefits known to aid in business identity such as hats or caps $(76 \%)$ and shirts $(71 \%)$. Employees were also given protection devices such as safety glasses $(78 \%)$, masks (74\%), gloves (71\%), back supports (48\%) and shoes or boots $(15 \%)$. There was a statistically significant correlation between the total annual payroll of companies and availability of medical $(P=0.046)$ and life insurance $(P=0.001)$ (Table 10). Companies with a larger annual payroll were more likely to provide medical and life insurance.

Past studies have indicated that workplace diversity promotes recruitment and retention of employees and affects management styles and relationships within the company. Minorities in homogenous institutions can be excluded and isolated, leading to employee dissatisfaction and, ultimately, a high turnover rate within the business (Ewert et al., 1995). Results from this study showed low employment among African Americans (1\%) and Asians (2\%) (Fig. 4). Recruitment of Hispanic employees is especially common for seasonal labor (HRDC, 1992), which likely explains the higher percentage of Hispanic employees reported in this study (46\%) (Fig. 4). Respondents indicated that $76 \%$ of their employees were male (Fig. 4). This was similar to past research that found fewer women working in the Florida ornamental horticulture industry, and most of the women employed in clerical positions (Smith et al., 1990). Respondents indicated that their employees were primarily between 21 and 41 years old $(64 \%)$, with only $10 \%$ over 52 years old (Fig. 4). These findings supported research showing a higher number of young people working in the industry in North America (HRDC, 1992).

The value of U.S. horticultural products is expected to continue growing through 2005 . Respondents in this study indicated that business proprietors forecast growth, as well, with most nursery businesses predicting $10 \%$ to $20 \%$ growth in their companies. There has been some concern whether 


\section{Extension Education Methods}

Table 7. Comparisons of industry survey responses on the variables of employees' length of service ${ }^{\mathrm{z}}$ and type of business structure ${ }^{\mathrm{y}}$ in which they were employed determined by an analysis of variance.

\begin{tabular}{|c|c|c|c|c|c|}
\hline $\begin{array}{l}\text { Years of } \\
\text { service }\end{array}$ & $\begin{array}{l}\text { Sumof } \\
\text { squares }\end{array}$ & df & $\begin{array}{l}\text { Mean } \\
\text { square }\end{array}$ & $\begin{array}{c}\mathbf{F} \\
\text { value }\end{array}$ & $\boldsymbol{P}$ \\
\hline Between groups & 35.235 & 3 & 11.745 & 4.910 & 0.003 \\
\hline Total & 334.233 & 128 & & & \\
\hline
\end{tabular}

${ }^{\mathrm{z}} 0$ through $16+$ years.

ySole proprietorship, corporation or limited liability.

Table 8. Post hoc analyses indicating the percentages of nonseasonal workers employed with each type of business structure for less than 1 year to 16 or more years as reported by industry survey responses $(n=147)$.

\section{Business structure} and length of service
Industry survey responses Nonseasonal workers (\%)

$<$ l year

Corporation

0

Sole proprietorship

Partnership

Limited liability corporation

1-2 years

Corporation

Sole proprietorship

Partnership

Limited liability corporation

3-5 years

Corporation

Sole proprietorship

Partnership

Limited liability corporation

6-7 years

Corporation

Sole proprietorship

Partnership

Limited liability corporation

8-10 years

Corporation

Sole proprietorship

Partnership

Limited liability corporation

11-15 years

Corporation

Sole proprietorship

Partnership

Limited liability corporation

$\geq 16$ years

Corporation

Sole proprietorship

Partnership

Limited liability corporation
5.1

10.0

0

0

0

16.7

35.9

20.0

0

24.4

7.7

20.0

0

23.1

17.9

40.0

100

12.8

2.6

0

0

20.5

12.8

10.0

0 there will be enough trainable or educated workers to meet the increased need for employees. Respondents in this study indicate that businesses were recruiting employees with various educational backgrounds including those with degrees in horticulture, business and related areas. These results demonstrate that knowledge and skills related to business can be as valuable as horticulture knowledge for students seeking positions in the industry. As such, universities may want to modify degree programs to promote business skills by offering minors in business or dual programs. Results from this study found that wages earned by horticultural laborers were exceedingly low. Low wages are often associated with difficulties in recruiting and retaining good employees. If the industry wishes to remain competitive, it may prove wise to consider implications that occur with high employee turnover. Finally, the information provided by this study provides valuable insight into the status of the industry, indicating that horticultural crops are a valuable industry in Illinois, providing employment opportunities as well as strengthening many local, rural economies. 
Table 9. Frequencies and percentages of the types of employee benefits provided by businesses as reported by industry survey responses $(\mathbf{n}=147)$.

\begin{tabular}{lcr}
\hline & \multicolumn{2}{c}{ Industrysurveyresponses } \\
\cline { 2 - 3 } Benefit & Businesses providingbenefits (no.) & Businesses providingbenefits (\%) \\
\hline Liability insurance & 83 & 59.3 \\
Medical insurance & 66 & 46.8 \\
Worker's compensation & 122 & 86.5 \\
Life insurance & 37 & 26.2 \\
Hats & 105 & 75.5 \\
Back supports & 67 & 48.2 \\
Shirts & 99 & 71.2 \\
Safety glasses & 109 & 78.4 \\
Shoes/Boots & 20 & 14.6 \\
Gloves & 98 & 70.5 \\
Masks & 103 & 74.1 \\
\hline
\end{tabular}

Table 10. The relationship between total annual payroll of businesses responding to the industry survey and the availability of medical and life insurance provided by those businesses to employees determined by using a Pearson product-moment correlation.

\begin{tabular}{lcc}
\hline Total annual payroll & Medical insurance & Life insurance \\
\hline Pearson correlation & 0.264 & 0.434 \\
$P(2$-tailed $)$ & 0.046 & 0.001 \\
Number & 58 & 58 \\
\hline
\end{tabular}

Dickson, W.J. 1973. Hawthorne experiment, p. 298-302. In: C. Heyel (ed.). The encyclopedia of management. $2^{\text {nd }}$ ed. Van Nostrand Reinhold, New York.

Ewert, D.M., J.K. Rice, and E. Lauderdale. 1995. Training for diversity: How organizations become more inclusive. Adult Learning 6(5):27-28.

Human Resources Development Canada. 1992. Horticulture industry report-A summary of the human resources study. $12 \mathrm{Jan}$. 2002. <http://www.hrdc-drhc.gc.ca/hrib/hrp-prh/ssd-des/ english/industryprofiles/R0l/busenv.shtml\#100>

Illinois Agricultural Statistics Service. 1997. Illinois agricultural statistics annual summary. Ill. Agr. Stat. Serv.,

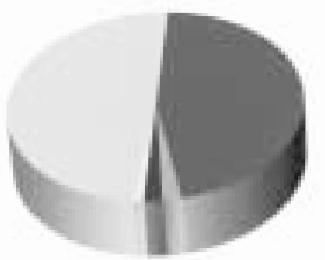

Ethnicity

Caucasian (51S)

Higpanic $(46 \%)$

Asise (2\%)

Atrican Amarican $(1 \%)$

Other (ON))

Fig. 4. Industry survey responses $(n=147)$ indicating the percentages of horticulture employees in each of the categories of ethnicity, gender and age.

\section{Literature cited}

Ayers D. and B. Stone. 1999. Extension organization of the future: linking emotional intelligence and core competencies. J. Ext. 37(6). 12 Jan. 2002. <http://www.joe.org/joe/1999december/ iw4.html>

Bordelon, B., A. Hammer, B. Moser, J. Simon, G. Sullivan, and J. Uhl. 1997. Food system 21: Gearing up for the new millennium. Purdue Univ. Coop. Ext. Serv., West Lafayette, Ind.

Borg, W.R. and M.D. Gall. 1989. Educational research: An introduction. $5^{\text {th }}$ ed. Longman, White Plains, N.Y.
Springfield.

Lard, C.F., C.R. Hall, and R.K. Berry. 1996. The economic impact of the Texas turfgrass industry. Hort. Econ. Res. Rpt. \#96-9. Dept. Agr. Econ., Texas A\&M Univ., College Station.

Lindner, J.R. 1998. Understanding employee motivation. J. Ext. 36(3). 12 Jan. 2002. <http://www.joe.org/joe/1998june/ rb3.html>

Putnam, J. and J. Allshouse. 1996. Food consumption, prices, and expenditures. USDA Stat. Bul. 928, April.

Rhodus, T. and J. Hoskins. 1996. Ohio nursery industry survey. Department of Horticulture and Crop Science, Ohio State University. 12 Jan. 2002. <http://www.hcs.ohiostate.edu/greengoods/survey96.htm>

Smith, S., M.E. Swisher, and C. Shehan. 1990. Targeting women in agribusiness. J. Ext. 28(4). 12 Jan. 2002. <http://www.joe.org/ joe/1990winter/a8.html>

Tinker Graphics. 1994. Jobs in horticulture. 21 Jan. 2002. <http:/ /hortjobs.com/>

U.S. Department of Agriculture. 1997. Vegetables and specialties: Situation and outlook report. Market and Trade Econ. Div., Econ. Res. Serv., VGS-271, April.

U.S. Department of Agriculture. 1998. Census of agriculture horticulture specialties. vol. 3. Natl. Agr. Stat. Serv. 12 Jan. 2002. <http://www.nass.usda.gov/il/1998/> 